\title{
Management and survival of patients with lung cancer in Scotland diagnosed in 1995: results of a national population based study
}

A Gregor, C S Thomson, D H Brewster, P L Stroner, J Davidson, R J Fergusson, R Milroy, on behalf of the Scottish Cancer Trials Lung Group and the Scottish Cancer Therapy Network
Lothian University Hospitals NHS Trust, Edinburgh EH4 2XU, UK

A Gregor

R J Fergusson

Scottish Cancer Intelligence Unit, Information and Statistics Division, Trinity Park House, Edinburgh EH5 3SQ, UK

C S Thomson

D H Brewster

P L Stroner

Scottish Cancer Therapy Network, North of Scotland Regional Office, Aberdeen Royal Infirmary, Aberdeen AB9 2ZB, UK

J Davidson

Stobhill NHS Trust, Glasgow G21 3UW, UK R Milroy

Correspondence to: Dr A Gregor anna.gregor@ed.ac.uk

Received 26 June 2000 Returned to authors 18 September 2000 Revised version received 24 November 2000 Accepted for publication 24 November 2000

\begin{abstract}
Background-The prognosis of patients with lung cancer in Scotland is poor and not improving. This study was designed to document factors influencing referral, diagnostic evaluation, treatment, and survival in patients with lung cancer.

Methods-Patients diagnosed during 1995 were identified from the Scottish Cancer Registry and their medical records were reviewed. Adequate records were available in $91.2 \%$ of all potentially eligible cases.

Results-In 1995, patients in Scotland with lung cancer had a high rate of microscopic verification $(74.1 \%)$ and $75.3 \%$ were assessed by a respiratory physician; however, only $56.8 \%$ received active treatment (resection $10.7 \%$, radiotherapy $35.8 \%$, chemotherapy $16.1 \%$ ) and $2.9 \%$ participated in a clinical trial. Survival was poor with a median of 3.6 months; $21.1 \%$ (95\% CI $19.8 \%$ to $22.4 \%$ ) were alive at 1 year and $7.0 \%(95 \%$ CI $6.2 \%$ to $7.8 \%)$ at 3 years. Management by respiratory physician, oncologist, or thoracic surgeon was an independent predictor of access to potentially curative treatment and better survival.

Conclusion-This national population based study demonstrates low use of treatment, poor survival, and the influence of process of care on survival. Implementation of evidence-based guidelines will require substantial changes in practice. Increasing the number of patients who receive treatment may improve survival.

(Thorax 2001;56:212-217)
\end{abstract}

Keywords: lung cancer; medical audit; outcome; health care assessment

Lung cancer is a major cause of morbidity and mortality. Over 4500 people are diagnosed with primary lung cancer in Scotland every year ${ }^{1}$ and 3948 deaths from the disease were registered in $1998 .^{2}$ Fewer than $5 \%$ of patients remain alive 5 years after diagnosis and survival prospects have changed little in the last 20-25 years. ${ }^{3}$ Higher rates and improving survival (5 year relative survival up to $14 \%$ ) reported by some European countries raise the possibility that there may be opportunities for improvement. ${ }^{4}$ A number of reasons exist for inter- national variations in survival, but one which has been raised is the poor access that patients with lung cancer in the UK have to specialised care and treatment. ${ }^{5}$

We aimed to document the process of care and to describe the main characteristics of lung cancer management in the Scottish population. An additional objective was to identify factors which influenced patterns of referral, diagnostic evaluation, choice of treatment, and determined survival.

\section{Methods}

Patients with lung cancer (ICD-9 162) diagnosed during 1995 were identified from the Scottish Cancer Registry. Permission to examine medical records was obtained from the directors of public health of each health board and the medical directors of all NHS trusts and relevant groups of clinicians (respiratory physicians, oncologists, and thoracic surgeons). All NHS trusts and consultants cooperated with data collection. Specially trained Scottish Cancer Therapy Network (SCTN) data managers examined all available medical records and abstracted a standard set of information using common data definitions. Data quality was checked by independent review of a random sample of cases. Multiple searches were performed in cases with multiple medical records. The data set contains information on referral patterns, clinical presentation, diagnostic and staging evaluation, clinical extent of disease, pathology, and treatment received within 6 months of diagnosis. Prognostic factors such as weight loss or performance status were noted when available in the medical records. We did not collect information on co-morbidity or smoking history.

Demographic information included age, sex, and patient's postcode of residence. The census based Carstairs deprivation index ${ }^{6}$ was derived from each patient's postcode and enabled us to allocate patients to one of five quintiles of the Scottish population ( $1=$ least deprived, $5=$ most deprived). To permit survival analysis the Registrar General's death records up to the end of 1998 were linked to the study population by probability matching. ${ }^{7}$

\section{DEFINITIONS USED IN THE STUDY}

Date of diagnosis: defined, in order of priority, as date of histological confirmation (excluding at necropsy) or cytological confirmation, or diagnostic radiology, or diagnostic clinical examination. 
Lung cancer specialist: respiratory physicians, thoracic surgeons or oncologists. (The specialties of consultants were assigned using the Manpower database held at the Information \& Statistics Division of the NHS in Scotland supplemented by the British Thoracic Society Directory of Respiratory Medicine Services to ensure correct classification of respiratory and general physicians.)

Active treatment: any specific anti-cancer treatment-that is, surgical resection, any chemotherapy, or radiotherapy-within 6 months of diagnosis.

Potentially curative treatment: a sub-category of active treatment:

(a) resection in patients with localised tumour of any histological category;

(b) patients with localised tumour without proven small cell lung cancer (SCLC) receiving high dose ( $\geqslant 50$ Gy) chest irradiation;

(c) patients with proven SCLC with either localised or regional tumour treated with combination chemotherapy.

STATISTICAL METHODS

The descriptive statistics presented for the variables are means, medians, ranges, and interquartile ranges. Associations between pairs of variables were examined using the $\chi^{2}$ test.

Several univariate logistic regression models were fitted to determine which factors (related to patients, tumour, or process of care factors) predicted whether or not patients received potentially curative treatment. Odds ratios are presented for each level of the different factors compared with baseline. The factors were further examined using a single logistic multivariate regression $\operatorname{model}^{8}$ to examine the effect of each of the factors after adjustment for other factors included in the model. Interactions between factors were investigated to determine whether particular combinations of factors had a greater effect. These analyses were based on the subgroup of patients who were documented as having either localised disease for any cell type or those patients having SCLC and regional disease. This subgroup was chosen as the cohort for the logistic regression

Table 1 Derivation of the study population

\begin{tabular}{lc}
\hline & No of cases \\
\hline Held by the Scottish Cancer Registry & 4465 \\
Ineligible cases & \\
Diagnosis >3 months outside 1995 & 102 \\
Diagnosed and treated outside Scotland & 13 \\
Not primary cancer of the lung & 79 \\
Incidental finding at necropsy & 28 \\
Ineligible for other reasons & 18 \\
Total ineligible & 240 \\
Eligible (or potentially eligible) cases & 4225 \\
Cases with inadequate/unavailable records & 38 \\
Insufficient information available & 89 \\
Medical records destroyed & 243 \\
Medical records not located & $370 \dagger$ \\
Total with inadequate or unavailable records & 3855 \\
Study population $\ddagger$ & \\
\hline
\end{tabular}

*At the time of commencement of the study.

+102 of these cases had been registered on the basis of information from death certificates only.

$\$ 91.2 \%$ of eligible (or potentially eligible) cases. modelling as it represented those patients who had the possibility of receiving potentially curative treatment.

Kaplan-Meier survival analysis was performed to plot survival curves and to estimate the median survival and point estimates of 1 and 3 year survival. Both univariate and multivariate hazard ratios of death were obtained using Cox's proportional hazards models. ${ }^{9}$ Again, the factors examined were the patient related, tumour related, and process of care related factors. The univariate figures were derived by including each factor separately in a different model. A multivariate Cox model containing only the main effects for these factors was then obtained. The end point for these survival analyses was death from any cause.

\section{Results}

The study population, derived using predefined eligibility criteria, is summarised in table 1. A total of 4465 patients with lung cancer were recorded in the Scottish Cancer Registry for the year 1995 at the start of data collection. Relevant medical records were obtained for $91.2 \%$ of eligible or potentially eligible cases. Of the 370 patients for whom medical records were not available, 102 were registrations based on death certificates only. These 370 patients were more likely to be $\geqslant 80$ years of age $(p=0.02)$ and resident in the most deprived quintile $(p<0.001)$. These biases could not be corrected for in subsequent analyses.

The study population was elderly (median 70 years; range 34-97) and predominantly male $(61 \%)$, with over $26 \%$ falling into the most deprived quintile (table 2 ).

In 3116 patients $(81 \%)$ we knew the dates of initial hospital referral and diagnosis. The

Table 2 Demographic and case mix characteristics $(n=3855)$

\begin{tabular}{|c|c|c|}
\hline Characteristic & No & $\%$ \\
\hline \multicolumn{3}{|l|}{ Age group (years) } \\
\hline$<60$ & 577 & 15.0 \\
\hline $60-69$ & 1268 & 32.9 \\
\hline $70-79$ & 1444 & 37.5 \\
\hline$\geqslant 80$ & 566 & 14.7 \\
\hline \multicolumn{3}{|l|}{ Sex } \\
\hline Male & 2341 & 60.7 \\
\hline Female & 1514 & 39.3 \\
\hline \multicolumn{3}{|l|}{ Carstairs deprivation quintiles } \\
\hline 1 (least deprived) & 533 & 13.8 \\
\hline 2 & 648 & 16.8 \\
\hline 3 & 800 & 20.8 \\
\hline 4 & 840 & 21.8 \\
\hline 5 (most deprived) & 1034 & 26.8 \\
\hline \multicolumn{3}{|l|}{ Clinical extent of disease } \\
\hline Localised & 1252 & 32.5 \\
\hline Regional spread & 976 & 25.3 \\
\hline Distant spread & 1204 & 31.2 \\
\hline Not known & 423 & 11.0 \\
\hline \multicolumn{3}{|l|}{ Microscopically verified } \\
\hline Histologically verified & 2081 & 54.0 \\
\hline Cytology only & 775 & 20.1 \\
\hline Not microscopically verified & 999 & 25.9 \\
\hline \multicolumn{3}{|l|}{ Morphology of tumour ${ }^{\star}$} \\
\hline Squamous cell carcinoma & 1106 & 38.7 \\
\hline Small cell carcinoma & 678 & 23.7 \\
\hline Adenocarcinoma & 557 & 19.5 \\
\hline Othert & 408 & 14.3 \\
\hline Not recorded/not known & 107 & 3.7 \\
\hline
\end{tabular}

*Percentages for morphology of tumour are for those having microscopic verification $(74.1 \%)$.

tUndifferentiated non-small cell carcinoma, large cell carcinoma, mixed histology, or other histology. 
median interval between these was 11 days (interquartile range 4-25). Lung cancer specialists assessed $2703(87 \%)$ of these 3116 patients during the first 6 months from diagnosis (median time interval 7 days; interquartile range $1-16)$.

In 2531 patients $(65.7 \%)$ the diagnosis was established by a respiratory physician and 2901 patients $(75.3 \%)$ were managed or reviewed by a respiratory physician during the first 6 months of care. Oncologists diagnosed 18 patients $(0.5 \%)$ and 2030 patients $(52.7 \%)$ were seen by one during the first 6 months of their care. Thoracic surgeons confirmed the diagnosis in 118 patients $(3.1 \%)$ and managed $739(19.2 \%)$. Two or more lung cancer specialists were involved in 2048 patients $(53.1 \%)$. In the 1188 patients $(30.8 \%)$ not diagnosed by lung cancer specialists, general physicians diagnosed $41.2 \%$, geriatricians $28.5 \%$, and general surgeons $11.2 \%$. There were 487 patients $(12.6 \%)$ who did not see any lung cancer specialist in the 6 months from diagnosis.

Common investigations included a chest radiograph in $99 \%$, routine haematological tests in $91 \%$, biochemistry in $90 \%$, bronchoscopy in $67 \%$, computed tomographic (CT) scan of the chest in $47 \%$, liver ultrasound scan in $24 \%$, bone scan in $18 \%$, CT scan of the abdomen in $18 \%$, and CT scan of the brain in $10 \%$. The median number of investigations (excluding clinical examination) per patient was 5 (range $0-9$ ). Fourteen patients had only clinical examination recorded in their notes.

Details of staging and staging procedures recorded in the case notes were inconsistent and variable. The data managers evaluated the available staging information and grouped patients into categories (localised, regional, and metastatic disease). In 423 patients (11\%) this was not possible because of poor or missing information (table 2).

A tissue diagnosis was obtained in 2081 $(72.9 \%)$ of the $2856(74.1 \%)$ microscopically verified patients (table 2). Of the 2520 patients $(65.4 \%)$ in whom a biopsy or cytological specimen was taken at bronchoscopy, a positive diagnosis was obtained in 1877 (74.5\%). Other diagnostic tests which were performed (and were positive) were: sputum cytology in 878 (265), biopsy of metastases in 482 (320), pleural aspirate in 274 (121), and fine needle aspiration of the lung in 424 (326). Of the microscopically verified tumours, the main histological subtypes were squamous cell carcinoma $(38.7 \%)$, SCLC $(23.7 \%)$, and adenocarcinoma $(19.5 \%)$. In 107 patients $(3.7 \%)$ the cell type was unknown (in addition to the further 999 cases who were not microscopically verified). There were significantly more women with SCLC and adenocarcinoma and a corresponding excess of squamous cell cancers in men $(\mathrm{p}<0.001)$.

Table 3 summarises the treatment received by patients in the first 6 months following diagnosis. In all, $601(15.6 \%)$ underwent a surgical procedure: mediastinoscopy only in $154(4.0 \%)$; exploratory thoracotomy in 36 $(0.9 \%)$; and $411(10.7 \%)$ had their cancers resected, most commonly by lobectomy (226 cases). Radiotherapy was received by 1381 patients $(35.8 \%)$ with a palliative schedule in $87.7 \%$. Radiotherapy to the primary tumour was administered to 1188 patients (30.8\%) and $106(2.7 \%)$ received a radical dose $(\geqslant 50 \mathrm{~Gy})$. Chemotherapy was given to 621 patients $(16.1 \%)$ including $425(62.7 \%)$ of the 678 cases with documented SCLC and 1667 patients $(43.2 \%)$ received no active treatment.

Potentially curative treatment was delivered to 627 patients, which represents $16.3 \%$ of all patients and $44.1 \%$ of the 1423 with tumour extent permitting such an approach. Table 4 shows the univariate and multivariate odds ratios predicting the use of potentially curative treatment. The variable for clinical extent of disease was not offered to these models because of the definition of potentially curative treatment. In the univariate analyses age, histological examination, and the process of care (referral by, diagnosis by, or referral to a lung cancer specialist within 6 months) all affected the chances of receiving potentially curative treatment. The multivariate analysis gave adjusted odds ratios for levels for each of the factors after adjustment for the other factors in the model. All of the factors remained significant, but no interactions between factors were statistically significant. Prognostic factors such as performance status or weight loss could not be tested because they were recorded in only $2 \%$ and $39 \%$ of cases, respectively.

Table 3 Treatment within 6 months of diagnosis $(n=3855)$

\begin{tabular}{|c|c|c|}
\hline Treatment & Number & $\%$ \\
\hline \multicolumn{3}{|l|}{ Any active treatment within 6 months } \\
\hline Yes & 2188 & 56.8 \\
\hline No & 1667 & 43.2 \\
\hline \multicolumn{3}{|l|}{ Surgery } \\
\hline Resection & 411 & 10.7 \\
\hline Thoracotomy (not resectable) & 36 & 0.9 \\
\hline No surgery ${ }^{\star}$ & 3408 & 88.4 \\
\hline \multicolumn{3}{|l|}{ Radiotherapy } \\
\hline No radiotherapy & 2474 & 64.2 \\
\hline Radiotherapy to chest $\geqslant 50 \mathrm{~Gy} \ddagger$ & 106 & 2.7 \\
\hline Radiotherapy to chest $<50$ Gy 9 & 1078 & 28.0 \\
\hline Radiotherapy to other sites only & 193 & 5.0 \\
\hline \multicolumn{3}{|l|}{ Chemotherapy ${ }^{\star \star}$} \\
\hline \multicolumn{3}{|l|}{ SCLC $(n=678)+\dagger$} \\
\hline Single agent & 87 & 12.8 \\
\hline Combination & 337 & 49.7 \\
\hline No chemotherapy & 253 & 37.3 \\
\hline \multicolumn{3}{|l|}{$\operatorname{NSCLC~}(n=2071) \ddagger \ddagger$} \\
\hline Single agent & 88 & 4.2 \\
\hline Combination & 82 & 4.0 \\
\hline No chemotherapy & 1901 & 91.8 \\
\hline \multicolumn{3}{|l|}{ Not known $(\mathrm{n}=1106)$ ฯा } \\
\hline Single agent & 11 & 1.0 \\
\hline Combination & 15 & 1.4 \\
\hline No chemotherapy & 1080 & 97.6 \\
\hline \multicolumn{3}{|l|}{ Entry into clinical trials } \\
\hline Yes & 110 & 2.9 \\
\hline No & 3745 & 97.1 \\
\hline
\end{tabular}

*Includes 154 patients who only had a mediastinoscopy.

†Four patients received unknown dose of radiotherapy to the chest.

$\ddagger$ One patient received both radiotherapy to the chest (dose $\geqslant 50 \mathrm{~Gy}$ ) and radiotherapy to another site.

997 patients received both radiotherapy to the chest (dose $<50 \mathrm{~Gy})$ and radiotherapy to another site.

$\star \star$ Percentages are of cases with a particular cell type.

H+One patient with SCLC received chemotherapy but the regimen was not recorded.

$\ddagger \ddagger$ Includes cases with a recorded histological type known not to be SCLC.

१ๆIncludes cases with type not known or not recorded and those with no microscopic verification. 
Table 4 Unadjusted ${ }^{\star}$ and adjusted $\dagger$ odds ratios of receiving potentially curative treatment for patients documented as having either localised disease for all histologies or regional disease for patients with small cell lung cancer (SCLC, $n=1423)$

\begin{tabular}{|c|c|c|c|c|c|c|}
\hline Factor & $\begin{array}{l}\text { No of cases }(\% \\
\text { of total) in } \\
\text { subgroup }\end{array}$ & $\begin{array}{l}\text { No (\%) } \\
\text { receiving PCT }\end{array}$ & $\begin{array}{l}\text { Unadjusted odds of } \\
\text { potentially curative } \\
\text { treatment }(95 \% \mathrm{CI})\end{array}$ & $p$ value $\neq$ & $\begin{array}{l}\text { Adjusted odds of } \\
\text { potentially curative } \\
\text { treatment }(95 \% \mathrm{CI})\end{array}$ & $p$ value \\
\hline \multicolumn{4}{|l|}{ Age group (years) } & \multicolumn{2}{|l|}{$<0.0001$} & $<0.0001$ \\
\hline$<60$ & $222(38.5)$ & $164(73.9)$ & 1.0 & & 1.0 & \\
\hline $6-69$ & $497(39.2)$ & $288(57.9)$ & $0.49(0.34$ to 0.69$)$ & & $0.51(0.36$ to 0.74$)$ & \\
\hline $7-79$ & $528(36.6)$ & $166(31.4)$ & $0.16(0.11$ to 0.23$)$ & & $0.20(0.14$ to 0.28$)$ & \\
\hline $80+$ & $176(31.1)$ & $9(5.1)$ & $0.02(0.01$ to 0.04$)$ & & $0.03(0.01$ to 0.06$)$ & \\
\hline \multicolumn{4}{|r|}{ 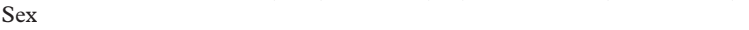 } & \multirow[t]{3}{*}{0.55} & & 0.49 \\
\hline Male & $850(36.3)$ & $380(44.7)$ & 1.0 & & 1.0 & \\
\hline Female & $573(37.8)$ & $247(43.1)$ & 0.94 (0.76 to 1.16$)$ & & $0.91(0.71$ to 1.18$)$ & \\
\hline \multicolumn{4}{|l|}{$\begin{array}{l}\text { Deprivation } \\
\text { quintile }\end{array}$} & \multirow[t]{6}{*}{0.68} & & 0.25 \\
\hline $\begin{array}{l}1 \text { (least } \\
\text { deprived) }\end{array}$ & $174(32.6)$ & $82(47.1)$ & 1.0 & & 1.0 & \\
\hline 2 & $235(36.3)$ & $106(45.1)$ & $0.92(0.62$ to 1.37$)$ & & $1.14(0.72$ to 1.80$)$ & \\
\hline 3 & $284(35.5)$ & $131(46.1)$ & $0.96(0.66$ to 1.40$)$ & & $1.07(0.69$ to 1.66$)$ & \\
\hline 4 & $319(38.0)$ & $134(42.0)$ & $0.81(0.56$ to 1.18$)$ & & $0.95(0.62$ to 1.47$)$ & \\
\hline $\begin{array}{l}5 \text { (most } \\
\text { deprived) }\end{array}$ & $411(39.7)$ & $174(42.3)$ & $0.82(0.58$ to 1.18$)$ & & $0.77(0.51$ to 1.16$)$ & \\
\hline \multicolumn{4}{|l|}{ Histology } & \multicolumn{2}{|l|}{$<0.0001$} & $<0.0001$ \\
\hline 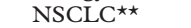 & $844(40.8)$ & $395(46.8)$ & 1.0 & & 1.0 & \\
\hline SCLC & $351(51.8)$ & $214(61.0)$ & 1.78 (1.38 to 2.29$)$ & & $2.20(1.64$ to 2.94$)$ & \\
\hline Not known†† & $228(20.6)$ & $18(7.9)$ & $0.10(0.06$ to 0.16$)$ & & $0.18(0.11$ to 0.30$)$ & \\
\hline \multicolumn{4}{|c|}{ Diagnosis by or referral to a specialist within 6 months of diagnosis } & \multirow[t]{3}{*}{$<0.0001$} & & 0.0002 \\
\hline Yes & 1339 (39.8) & $625(46.7)$ & 1.0 & & 1.0 & \\
\hline No & $84(17.2)$ & $2(2.4)$ & $0.03(0.01$ to 0.12$)$ & & $0.06(0.01$ to 0.27$)$ & \\
\hline
\end{tabular}

PCT $=$ potentially curative treatment.

$\star$ In separate logistic regression models.

†In a multivariate logistic regression model.

$\neq \mathrm{p}$ values for the factors are the Wald statistics for the estimates in the model.

Ip values for the factors are the Wald statistics for the estimates in the model, conditional on the other factors being present.

$\star \star$ Includes cases with a recorded histological type known not to be SCLC.

t†Includes cases with type not known or not recorded and those with no microscopic verification.

The Kaplan-Meier survival figures at 1 and 3 years were $21.1 \%$ (95\% CI $19.8 \%$ to $22.4 \%$ ) and $7.0 \%$ (95\% CI $6.2 \%$ to $7.8 \%$ ), respectively, and the median survival was 3.58 months (fig 1A). Figure 1B presents KaplanMeier survival curves for patients receiving potentially curative treatment, those receiving palliative treatment, and patients receiving supportive care only. Table 5 shows the
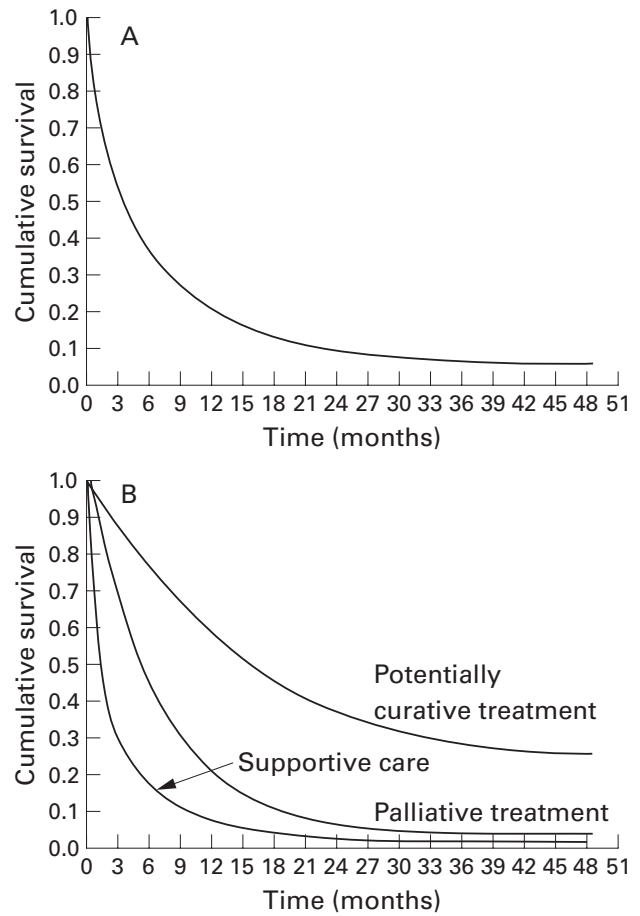

Figure 1 (A) Overall survival curve for all patients. (B) Kaplan-Meier survival curves for the different treatments given within 6 months. unadjusted and adjusted relative hazard ratios of death for clinical prognostic factors, process of care, and treatment using Cox's proportional hazards models based only on main effects.

In the unadjusted Cox's models all factors apart from sex were highly significant. In the multivariate model the factors for potentially curative treatment and surgical resection were not included as both of these factors are contained within the active treatment variable. Sex became significant $(p=0.0001)$, with women having a lower hazard of death. Deprivation remained statistically significant $(\mathrm{p}=0.003)$, with patients living in the most deprived quintile having a significantly higher risk of death than those resident in the least deprived quintile. Patients with distant metastases and patients with SCLC had poor survival. Patients managed by a lung cancer specialist had a higher probability of survival, as had patients receiving any form of active treatment.

\section{Discussion}

Previous studies in Scotland have been conducted in selected patient populations ${ }^{10} 11$ or focused on a defined aspect of practice. ${ }^{12}$ The remit of the Scottish Cancer Therapy Network $^{13}$ to document clinical practice before the development and dissemination of evidencebased clinical guidelines for lung cancer ${ }^{14}$ supported this evaluation of clinical practice in a national population of patients with lung cancer.

Information extracted from standard hospital and primary care records is limited by the availability of certain prognostic factors, ${ }^{15} 16$ accurate staging, ${ }^{17}$ co-morbidity, and inability to assess symptom control or patients' quality 
Table 5 Unadjusted* and adjusted ${ }^{*}$ hazard ratios of death with a minimum of 3 years follow up, based on all cases $(n=3855)$

\begin{tabular}{|c|c|c|c|c|}
\hline Factor & $\begin{array}{l}\text { Unadjusted hazard of } \\
\text { death }(95 \% \mathrm{CI})\end{array}$ & $p$ value $\neq$ & $\begin{array}{l}\text { Adjusted hazard of } \\
\text { death }(95 \% \text { CI })\end{array}$ & $p$ value \\
\hline Age group (years) & & $<0.0001$ & & $<0.0001$ \\
\hline$<60$ & 1.0 & & 1.0 & \\
\hline $60-69$ & 1.15 (1.04 to 1.28$)$ & & $1.10(0.99$ to 1.22$)$ & \\
\hline $70-79$ & $1.53(1.38$ to 1.69$)$ & & $1.34(1.21$ to 1.49$)$ & \\
\hline $80+$ & $2.23(1.97$ to 2.51$)$ & & $1.42(1.24$ to 1.63$)$ & \\
\hline Sex & & 0.28 & & 0.0001 \\
\hline Male & 1.0 & & 1.0 & \\
\hline Female & $0.96(0.90$ to 1.03$)$ & & $0.88(0.82$ to 0.94$)$ & \\
\hline Deprivation quintile & & 0.0033 & & 0.0033 \\
\hline 1 (least deprived) & 1.0 & & 1.0 & \\
\hline 2 & $0.99(0.88$ to 1.11$)$ & & 1.05 (0.93 to 1.19$)$ & \\
\hline 3 & $1.03(0.92$ to 1.16$)$ & & $1.11(0.99$ to 1.24$)$ & \\
\hline 4 & $1.06(0.94$ to 1.18$)$ & & $1.12(1.00$ to 1.25$)$ & \\
\hline 5 (most deprived) & $1.18(1.06$ to 1.31$)$ & & $1.22(1.10$ to 1.36$)$ & \\
\hline $\begin{array}{l}\text { Clinical extent of } \\
\text { disease }\end{array}$ & & $<0.0001$ & & $<0.0001$ \\
\hline Localised & 1.0 & & 1.0 & \\
\hline Regional spread & 1.64 (1.51 to 1.80$)$ & & $1.61(1.47$ to 1.75$)$ & \\
\hline Distant spread & $3.09(2.83$ to 3.37$)$ & & 2.81 (2.57 to 3.07$)$ & \\
\hline Not known & $2.85(2.54$ to 3.19$)$ & & $1.80(1.59$ to 2.03$)$ & \\
\hline Histology & & $<0.0001$ & & $<0.0001$ \\
\hline 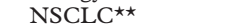 & 1.0 & & 1.0 & \\
\hline SCLC & $1.37(1.25$ to 1.50$)$ & & $1.27(1.16$ to 1.40$)$ & \\
\hline Not knownt† & $1.90(1.76$ to 2.05$)$ & & $1.05(0.96$ to 1.14$)$ & \\
\hline $\begin{array}{l}\text { Diagnosis by or referral } \\
\text { to specialist within } 6 \\
\text { months }\end{array}$ & & $<0.0001$ & & $<0.0001$ \\
\hline Yes & 1.0 & & 1.0 & \\
\hline No & $3.71(3.36$ to 4.10$)$ & & $1.95(1.75$ to 2.18$)$ & \\
\hline $\begin{array}{l}\text { Active treatment within } \\
6 \text { months }\end{array}$ & & $<0.0001$ & & $<0.0001$ \\
\hline Yes & 1.0 & & 1.0 & \\
\hline No & 2.69 (2.51 to 2.88$)$ & & 2.04 (1.88 to 2.21$)$ & \\
\hline $\begin{array}{l}\text { Potentially curative } \\
\text { treatment within } 6 \\
\text { months }\end{array}$ & & $<0.0001$ & Not applicableł‡ & \\
\hline Yes & 1.0 & & & \\
\hline No & $3.31(2.99$ to 3.66$)$ & & & \\
\hline $\begin{array}{l}\text { Surgical resection } \\
\text { within } 6 \text { months }\end{array}$ & & $<0.0001$ & Not applicable $\ddagger \ddagger$ & \\
\hline Yes & 1.0 & & & \\
\hline No & 4.47 (3.92 to 5.10$)$ & & & \\
\hline
\end{tabular}

^Derived from univariate Cox's proportional hazards model.

†Derived from a multivariate Cox's proportional hazards model

$\neq \mathrm{p}$ values for the factors are the Wald statistics for the estimates in the model, conditional on the other factors being present.

ๆp values for the factors are the Wald statistics for the estimates in the model, conditional on the other factors being present.

${ }^{\star \star}$ Includes cases with a recorded histological type known not to be small cell lung cancer (SCLC). H+Includes cases with type not known or not recorded and those with no microscopic verification. ¥Neither the potentially curative treatment nor surgical resection factors were offered to the multivariate Cox model.

of life. It represents, however, the reality of documentation of care for a large and unselected population in a "contemporary" setting of the NHS.

The Scottish Cancer Registry has high case ascertainment ${ }^{18}$ and accuracy ${ }^{19}$ and the study population represents a high proportion of potentially eligible cases. This may exceed $91.2 \%$ since a proportion of the patients for whom records could not be traced may not have been eligible.

We have targeted data collection on the first 6 months following diagnosis which should have captured all primary treatment. ${ }^{14}{ }^{20}$ It may, however, underestimate the lifetime use of palliative treatments.

Survival was poor with a median survival of 3.58 months (SCLC 3.65; NSCLC 5.19; no microscopic verification or unknown type: 2.00 ) and survival at 3 years of $7 \%$, similar to national survival figures for the period of diagnosis $1991-5 .^{3}$ The survival disadvantage for patients from deprived communities has been confirmed in national analyses based on routine cancer registry data, even when causespecific mortality is used as the end point. ${ }^{3}$

Factors predicting better survival were female sex, localised disease, administration of any active treatment within 6 months of diagnosis, and also involvement of a lung cancer specialist. These results should be interpreted in the knowledge that it has not been possible to adjust for all potentially important confounding factors, and the adjustment for clinical extent of disease may reflect variations in staging.

The most disturbing feature in this report is the low rate of treatment provision and evidence that factors such as patient's age ${ }^{21}$ and process of care $^{22}$ continue to influence outcome.

Potentially curative treatment was used in only $44 \%$ of patients with a tumour suitable for such an approach and the probability of receiving potentially curative treatment diminished with increasing age. Patients aged under 60 were five times more likely to be given potentially curative treatment than those in the $70-79$ age group, and 33 times more likely than patients over 80 years of age. Patients managed by a lung cancer specialist were 16 times more likely $(p<0.0001)$ to receive potentially curative treatment than those managed by other clinicians. The influence of co-morbidity on selection for potentially curative treatment could not be tested, although it seems unlikely to account for such substantive differences.

The resection rate of $11 \%$ is similar to the UK average ${ }^{23}$ but low compared with the $20-25 \%$ reported by other countries. ${ }^{24}$ This could be due to late presentation and a greater proportion of advanced disease or comorbidity in the Scottish population. Thoracic surgeons were involved in decision making in only $19 \%$ of patients and determination of operability on radiological grounds or selection by age may reduce resection rates inappropriately ${ }^{25}$ and deprive a patient of a chance of cure.

High dose chest radiotherapy, another potentially curative treatment option, was used in $53(10.6 \%)$ of the 502 patients with localised NSCLC who were not resected. This represents a major difference in practice compared with other countries where this is the standard treatment. ${ }^{26}$ It may reflect the poor provision of radiotherapy facilities in Scotland and a lack of specialist interest in lung cancer among clinical oncologists. $^{27}$

Despite evidence for the benefit of chemotherapy in patients with NSCLC, ${ }^{28}$ only $8.2 \%$ of this subgroup of patients in our study population received it. Even in SCLC, for which it is a standard treatment, only $62.7 \%$ of patients received any chemotherapy, and combination chemotherapy, which has been shown to be more active than single agent chemotherapy, ${ }^{29}$ was used in less than half of these patients.

Patients with SCLC who respond to chemotherapy have been shown to benefit from thoracic irradiation ${ }^{30}$ and prophylactic cranial irradiation. ${ }^{31}$ Although we did not attempt to collect data on the response to chemotherapy, only 48 patients with a localised or regional tumour of SCLC type received thoracic 
irradiation (33 without prophylactic cranial irradiation) and 19 received prophylactic cranial irradiation (four without thoracic irradiation) after combination chemotherapy.

Each of these interventions brings a small absolute survival benefit (5-10\%) but, cumulatively, these are capable of raising the population based survival to levels reported from other countries. The long term strategy for lung cancer must remain primary prevention through tobacco control, but if patients already destined to develop lung cancer in the first two decades of this millennium are to have a better chance of survival, a larger proportion must receive appropriate treatments. The modernisation of the NHS - particularly the wider evidence-based clinical guidelines, adoption of multidisciplinary management, and better access to specialist care through the development of clinical networks-may increase the use of active treatment. Earlier diagnosis may be achieved by referral guidance and the use of new diagnostic tools. In Scotland the accreditation process developed by the Clinical Standards Board will, using data collected mainly prospectively, test clinical services against evidence-based standards and raise awareness of appropriate treatment interventions among clinicians, patients, and carers. All of these initiatives are capable of incremental improvements in the management of patients with lung cancer. This report represents a baseline from which to measure improvements in the processes of care and outcome in this disadvantaged patient population.

Members of the Scottish Cancer Trials Lung Group (SCTLG) are: Dr A Gregor (chair), Dr D H Brewster, Dr P Brown, Dr D J Dunlop, Dr M Fallon, Dr R J Fergusson, Dr R Jones, Dr K M Kerr, Mr A J Kirk, Dr J B MacDonald, Mr J McPhelim, Dr R Milroy, Dr M Nicolson, Dr N O'Rourke, Professor A Price, Professor E Rankin, Dr M Storrie, Dr A White.

The authors wish to thank members of the former Scottish Lung Cancer Focus Group for their help with the design of the study; the other SCTN data managers for their help with data validation and support; and Mrs $\mathrm{H}$ Brown and members of the SCTLG for their comments on the text.

Funding: The Scottish Cancer Therapy Network is funded by (CRAG) and the Chief Scientist Office (CSO), both of the Scottish Executive Health Department. However, the views expressed in this paper are those of the authors.

1 Information \& Statistics Division. Scottish health statistics 1999. Edinburgh: ISD Scotland Publications, 2000.

2 Registrar General for Scotland. Annual report 1998. Edinburgh: General Register Office for Scotland, 1999.

3 Scottish Cancer Intelligence Unit. Trends in cancer survival in Scotland 1971-1995. Edinburgh: Information \& Statistics Division, 2000

4 Berrino F, Capocaccia R, Estève J, et al, eds. Survival of cancer patients in Europe: the EUROCARE-2 study. IARC cer patients in Europe: the EUROCARE-2 study. IARC
Scientific Publications No. 151. Lyon: International Scientific Publications No. 151. Lyon
Agency for Research on Cancer, 1999.
5 Janssen-Heijnen MLG, Gatta G, Forman D, et al, and the EUROCARE Working Group. Variation in survival of
patients with lung cancer in Europe, 1985-1989. Eur $\mathcal{F}$ patients with lung cance
Cancer 1998;34:2191-6.

6 Carstairs V, Morris R. Deprivation and health in Scotland. Aberdeen: Aberdeen University Press, 1991.

7 Kendrick S, Clarke J. The Scottish record linkage system. Health Bull 1993;51:72-9.

8 Armitage P, Berry G. Statistical methods in medical research. 3rd ed. Oxford: Blackwell Scientific Publications, 1994.

9 Collett D. Modelling survival data in medical research. London: Chapman \& Hall, 1994.

10 Fergusson RJ, Gregor A, Dodds R, et al, on behalf of the South East of Scotland Lung Cancer Group and Lothian Audit Office. Management of lung cancer in south east Scotland. Thorax 1996;51:569-74

11 Kesson E, Bucknall CE, McAlpine LG, et al. Lung cancer: management and outcome in Glasgow, 1991-92. Br f Cancer 1998;78:1391-5

12 McLean AN, Semple PA, Franklin DH, et al. The Scottish multi-centre prospective study of bronchoscopy for bronchial carcinoma and suggested audit standards. Respir Med 1998;92:1110-5.

13 Stroner PL, Brewster DH, Dewar JA, et al. In pursuit of excellence for patients with cancer: the Scottish Cancer Therapy Network model. Br f Cancer 1999;79:1641-5.

14 Scottish Intercollegiate Guidelines Network (SIGN). Management of lung cancer. Edinburgh: SIGN, 1998.

15 Feld R, Abratt RP, Groziano SL, et al. Pretreatment minimal staging and prognostic factors for non-small cell lung cancer. Lung Cancer 1997;17(Suppl 1):S3-10.

16 Stahel RA, Ginsbergh R, Haveman K, et al. Staging and prognostic factors in small cell lung cancer: consensus report. Lung Cancer 1989;5:119-26.

17 American Thoracic Society, European Respiratory Society. Pretreatment evaluation of non-small cell lung cancer. $\mathrm{Am}$ f Respir Crit Care Med 1997;156:320-32.

18 Brewster D, Crichton J, Harvey JC, et al. Completeness of case ascertainment in a Scottish Regional Cancer Registry for the year 1992. Public Health 1997;111:339-43.

19 Brewster D, Muir C, Crichton J. Registration of lung cancer in Scotland: an assessment of data accuracy based on review of medical records. Cancer Causes \& Control 1995;6: 303-10.

20 Joint Council for Clinical Oncology. Reducing delays in cancer treatments: some targets. London: Royal College of Physicians of London, 1993.

21 Brown JS, Erraut D, Trask C, et al. Age and the treatment of lung cancer. Thorax 1996;51:564-8.

22 Connolly CK, Jones WG, Thorogood J, et al. Investigation, treatment and prognosis of bronchial carcinoma in the Yorkshire region of England. Br f Cancer 1990;61:579-83.

23 Society of Cardiothoracic Surgeons of Great Britain and Ireland. UK Thoracic Surgical Register. 1994

24 Humphrey EW, Smart CR, Winchester DP, et al. National survey of the pattern of care for carcinoma of the lung. $\mathcal{F}$ Thorac Cardiovasc Surg 1990;100:837-43.

25 Dales RE, Stark RM, Raman S. Computed tomography to stage lung cancer: approaching a controversy using meta-analysis. Am Rev Respir Dis 1990;141:1096-101.

26 The Swedish Council on Technology Assessment in Health Care. Radiotherapy for Cancer. Volume 2. Acta Oncol 1996; Supplement 7.

27 Maher EJ, Timothy A, Squire CJ, et al. Audit: the use of radiotherapy for NSCLC in the UK. Clin Oncol 1993;5:72-

28 Non-Small Cell Lung Cancer Collaborative Group. Chemotherapy in non-small cell lung cancer: a metaanalysis using updated data on individual patients from 52 randomised trials. BMF 1995;311:899-909.

29 Medical Research Council Lung Cancer Working Party. Comparison of oral etoposide and standard intravenous multidrug chemotherapy for small cell lung cancer. Lancet 1996;348:563-6.

30 Pignon J-P, Arriagada R, Ihde DC, et al. A meta-analysis of thoracic radiotherapy for small cell lung cancer. $N$ Engl $\mathcal{F}$ Med 1992;237:1618-24.

31 Auperin A, Arriagada R, Pignon JP, et al. Prophylactic cranial irradiation for patients with small cell lung cancer in complete remission: a meta-analysis of individual data from 987 patients. $N$ Engl f Med 1999;341:476-84. 